\title{
Traveling Through and Traveling Within: Cinematic Constructions of Imaginative Geography of Croatia in the Films of the 2000s
}

\begin{abstract}
In this paper, I examine representations of Croatian identity in contemporary Croatian film through their links with the theme of travel. In particular, I look at practices of displacement as a specific element of travel writing, which "emerge as constitutive of cultural meanings rather than as their simple transfer of extension (Clifford 3; emphasis in the original). I argue that, following the emergence of physical borders after the break-up of Yugoslavia in the 1990s, Croatianness may be defined through the encounters with different types of travelers within the "complex and pervasive spectrum of human experiences" (Clifford 3). Their presence highlights not only "the discovery of places but also ... their creation" (Bishop 143), demonstrates that the imaginative geography of the country becomes "less a matter of physical geography than a qualitative assessment" (Bracewell and Drace-Francis 343), and turns its territory into a field for articulation of "different imaginative practices of foreignness" (Chard 9). In the paper, I explore this issue by looking at selected Croatian films of the first two decades of the 2000 s and divide them roughly into films featuring cinematic representations of external border crossings and those featuring allegorical travels within the country. What they have in common is engagement with the exploration of the country's newly created identity, its position within the wider identity of Europe, and the country's relationship with its own past. Films representative of the first group, such as Branko Schmidt's The Melon Route (Put Lubenica, 2006) or Ognjen Sviličić's Armin (2007) examine imaginary transitions between the mythical East and the mythologized West by featuring
\end{abstract}


various displaced characters, from former Yugoslav neighbors to illegal migrants, crossing into Croatia in search of the route to better life. Concurrently, travels within the Croatian territory, such as a search of what seems to be imagined medieval identity in Igor Bezinović's A Brief Excursion ( Kratki izlet, 2017), critically investigate mythologizing approaches to the national identity by delving into its past.

Keywords: Croatian cinema, travel writing, imaginative geography, migration on screen, borders on screen, space on film

An understanding of borders and space in general, "helps us to think acutely about the geophysical world and to consider how it is framed ideologically" (Williams xv). This means that it is necessary to think of borders in terms of narration: it is through narration that borders are constructed and imposed, but it is also through narration that identity, surrounded by those borders, is formed. As Klaus Eder argues about the borders in general, and European borders in particular, "borders are the object of a permanent process of telling and retelling stories from which emerge identities sometimes," and "the definition of the border constructions of Europe depends on how the stories about these borders are organized at a given point in time" (266). In contemporary Europe, the investigation of space and borders is based on different experiences of mobility, not just in terms of traveling across physical space, but also as a change of "nationality and culture, as well as one's own identity" (Rascaroli 74). Border crossing "has ceased to be the exception but become the rule itself" (Rascaroli 74), especially in the postmodern era, marked by global migrations, but also larger-scale political events and conflicts on the European continent, such as the Yugoslav Wars. Narratives surrounding borders and border-crossings are quite prominent in Croatian films of the 2000s, and they articulate what I consider dual, but often conflicting, Croatian and European identities of the country, the country's often marginally perceived position within European cultural discourse, and subject to different perspectives and interpretations. If, as Wendy Everett argues, film "reflects and creates identities; both reveals and composes the myths and images, which shape European vision and European identity," and films are "essential to the expression of national identity" (Everett 11), Croatian contemporary films construct this identity through the visualization of its imagined physical and metaphorical borders. By featuring the travel of different 
types of outsiders, Branko Schmidt's The Melon Route (2006) and Ognjen Sviličić's Armin (2007) investigate traditionally perceived position of Croatia as a geopolitical and cultural border-guard of European civilization, the narrative which resonates with other South-East European countries. Concurrently, Igor Bezinović's A Brief Excursion (2017) addresses mythologizing approaches to national identity by Croatia's attempts to constitute identity in relation to its perceived Europeanness from within, in this case in links with its medieval past. As Neven Budak argues, this phenomenon is significant for understanding the process of contemporary Croatia's nationbuilding, as "a means of establishing a new identity and escaping from reality" and, more specifically, because of "the traditional interpretation of Croatian history, which was seen by the nineteenth-century founding fathers of Croatian historiography as a continuous 'story' starting with the time of the settlement" (241). In this way, Croatian medieval past becomes a legitimizing device in the claims about the country's European identity.

The main premise of my paper is that these films reflect on the impact of the so-called "border in progress" (Graziano) on the creation of cultural and metaphorical borders, whose shifting position, both physical and metaphorical one, redefine how the country and its identity are perceived and represented. Croatia's recognizable geopolitical identity was established and confirmed first by the imposition of its own national borders during the break-up of Yugoslavia in the 1990s, and also regionally and globally within the conflicting process of European expansion affected by migrations - joining the borderless European Union in 2013 - as well as on-going preparations to join the Schengen Area, which at this moment is apparently only a matter of satisfying certain "technical criteria" ("Croatia"). The films provide fictionalized environment which reflects social and cultural changes, as well as an evolution of the geopolitical and cultural identity Croatia underwent during this period, from the war-related trauma and post-war recovery to its transition to capitalism. In the films in question, the cultural and geopolitical position of Croatia is revisited from the position of its external borders but also from within its territory. The presence of borders thus invites different interpretations of contemporary cultural issues emerging in the margins of Europe, as well as an examination of not only what, but also where the location of Croatian identity is $!^{[1]}$

The border between Croatia and Bosnia, which the protagonists cross in The Melon Route and Armin, is significant because of two on-going and conflicting processes related to the phenomenon 
of the European border in progress, which has an impact on how Croatia's identity is perceived. The first is the process of pushing the borders of official Europe toward the East, which has contributed not only to the "reshaping of Europe's borders" but also to "the rebirth of multiple contradictory ideas about the cultural identity of Europe itself" (Ravetto-Biagioli 181). As a result of this process, Croatia has become part of the West where internal borders are reduced from "the status of borders to pure spatial markers" (Bamyeh 35). At the same time, representing an external border of Europe, the Croatian-Bosnian border is significant because it positions Croatia as a border protector of the European Union, and makes it a privileged space where the identity is now formed in contrast to the perceived non-Europeanness of its neighbors, who once together with Croats were the citizens of Yugoslavia. In the films, such a border imposes a visible division between dream and history: while on the European side the drama of history is no longer important in the construction of identity and belonging, the space on the other side of the European border is a site where history and trauma are still lived and experienced. Conversely, my reading of A Short Excursion suggests that the theme of the journey is used in order to outline Croatia's internal struggles to identify and define its Europeanness and differentiate between the story, the fiction of belonging and the location of that belonging. The theme of the border and border-crossing seems to be distinctive when it comes to Croatia, and it has to do with the process of negotiating its European identity and joining the European Union.

An investigation of the theme of borders and crossings suggests similarities and novelties that Croatian cinematography brings to regional and European films on borders and migrations. Similar to contemporary regional and European cinematographic trends, ${ }^{[2]}$ Croatian films investigate different types of migration, from the global movement of people and human trafficking to local migrations. In this way, the theme of migration is used for the exploration of local and regional social and cultural issues, ${ }^{[3]}$ and as a proof that borders are not crumbling or dissolving, but instead "imposing a view of what (or who) belongs within and what belongs outside the national space" (Wood 121). However, as my analysis shows, Croatian films are specific in this context because of the war which continues to play the role in representation of the borders and identity, suggesting that belonging to an imagined and real Europe is only achievable when contemporary history is left behind, which proves to be impossible for the protagonists in The Melon Route and Armin. In the 
films, there is an apparent shift from the so-called discourse of self-Balkanization in post-Yugoslav cinemas, marked by "ethnocentric collectivism, rampant irrational stereotyping patriarchal machismo, and the culture of violence" as consequences of the war (Wood 112), to a reiteration of belonging to the West, which is now strengthened by the political reality of the EU membership ${ }^{[4]}$ In order to enter Croatian territories, or fulfil their dreams, one has to leave the memory of the war behind; Croatia's belonging to Europe is now formed on the opposition to its neighbors on its eastern and southern borders, which still live in the narrative of history. The (im)possibility of making a successful crossing to Croatia/Europe is now dependent on the (im)possibility of leaving the war and history behind.

\section{The Melon Route (2006; dir. by Branko Schmidt)}

The context of Melon Route is illegal human trafficking across the Sava River, which forms a natural boundary between Bosnia and Croatia. The film tells the story of the love between a Chinese girl, the only survivor of a boat accident in which her family dies, and Mirko, a local drug addict and an ex-war veteran suffering from PTSD. Melon is a pejorative name for the Chinese, who are transported across the continent in vans like melons. For human traffickers they are an example of how citizens of global superpowers become personae non gratae on the borders of Europe. This might be the reason why in the film the name of the Chinese girl, one of the protagonists, remains unknown.

The territory of Croatia is only implied in narration: positioned somewhere behind the trees on the other side of the river, Croatia as such represents an off-screen space which is suggested in conversations and by the camera-eye surveying the river as the natural border between the two countries. Following Andrè Gardies' typology of film space (1993), Croatia in The Melon Route could be described as being "there," the invisible space adjacent to that on the screen, or even "elsewhere," suggested orally by protagonists, which means in the realm of imagination. For instance, Mirko is warned that the Croatian border guards watched him save the Chinese girl, in this way suggesting the presence of an invisible, but omnipresent surveillance across the river. For the migrants, Croatia as such does not exist: the invisible space on the other side is supposed to be Germany, a location of their European Dream ${ }^{[5]}$ and possibly an idealized destination which 
Yosefa Loshitzky characterizes as Europe imagined according to its idyllic postcard representations, because of which it becomes known as "postcard Europe" (22-23). In Armin, in becomes apparent that this invisible space is actually what Augè identified as a non-place, where no stable identity can be formed, and, in extension, which exists only as a subject of interpretation. Conversely, in both films the border region of Bosnia partially corresponds to Augè's interpretation of an "anthropological place" - an opposition to non-space - which is characterized as "a bounded notion of place, localized in time and space" (Augè 78), and defined by a shared identity and history, where history is not represented, but present, undisputed, and lived. While this concept will be more visible in Armin, what makes it distinctive in Melon Route and only partially corresponding to Augè's description of an anthropological place is the presence of an excavation site from the recent war, where the presence of international experts working on the excavation and identification of human remains of war victims, and the EU border guards controlling the area, is visible. The visual motif of the European Union border guards patrolling the area evokes Étienne Balibar's reflections on "the ambiguity of the notions of interior and exterior" when it comes to the meaning of Europe, its location, and its identity. While Yugoslavia, along with some other Balkan countries, was considered an exterior space in the European narrative, when it came to military interventions, they became "fully inscribed within the borders of Europe" (Balibar 4).

The imminent, uninterrupted flow of the river as the geopolitical, natural, and metaphorical border toward Europe is the most pronounced spatial aspect of the film. An impression of its immensity is achieved by a panoramic and contemplative portrayal of the water, covered in fog and stretching across the screen. One might argue that in The Melon Route the Sava River - both physically and as a metaphor - comes to represent for the imaginative geography of Croatia what the Danube River represents for the territory of the Balkans and Central Europe in general: "a marker of transhistorical trauma" (Stob 142), which has always been perceived as "a defensive barricade against any aggressive Otherness" (Spiridon 381). There is no traffic on the river: there are only decayed boats anchored at its embankments, signaling that physical and metaphorical escape is not an option for everybody: while the anonymous girl continues her journey, Mirko, burdened by his own traumas, stays behind. His dilapidated house is also by the river, physically distant and isolated from the chaotic border town, as if pointing to his outsider's existence. As the events are unfolding 
and the story line becomes increasingly complex through the introduction of different characters and communities residing or traveling through the region, the river is portrayed as being something of a silent reminder of constancy and fate.

Other spaces are implied by sound, as "a pre-eminently spatial phenomenon in cinema" (Elsaesser and Hagener 137). As the Chinese girl searches for her dead relatives, her voice echoes across the river, suggesting an anonymous space stretching between her faraway homeland and the border of imagined Germany and real Croatia. The presence of the invisible, yet desired space on the other side of the river is further emphasized by the chaotic life of the border region. Ruled by the local mafia and corrupted state representatives, where different migrants, ethnic minorities, and nationalities $^{[6]}$ mix, from Russian sex workers to a traveling native Indian folklore group, it signifies the presence of the American Wild West, transposing the frontier myth to the border regions of Europe $^{[7]}$ However, it is not only their presence that makes the border region liminal; the border region is also the space where the memory of the recent war and current experiences of dying conflate. Mirko's uncle, otherwise a corrupted police officer, comments on the death of the Chinese by referring to his own experiences of the war and pointing to the excavation site where the remnants of Mirko's parents were just found: "poor people.... They'll remain in some anonymous hole, just like our people, without the name and the surname" (00:25:00). In this way the invisible space of Croatia/Europe exists in opposition to the global and spaceless nature of human suffering.

\section{Armin (2017; dir. by Ognjen Sviličić)}

In Armin, Ibro and his son Armin travel to Zagreb so that Armin can participate in an audition for a German film about Bosnia. As already mentioned in the context of The Melon Route, Bosnia is represented as an anthropological locality situated on the border with Croatia/the West, a place occupied by the indigenous inhabitants who live there, instead of the space, which is subject to different representations. Augè's concept of non-places is explicit in the film, however, with modifications stemming from the local context and the protagonists' circumstances. By crossing into the Croatian territory Ibro and Armin are not only passing strangers "who can feel at home there only in the anonymity of motorways, service stations, big stores or hotel chains" (Augè 106); 
the journey across the border is a transformation of the people who were once residents of the shared country into cultural outsiders and foreigners ${ }^{[8]}$ While The Melon Route is an artistic take on global migrations, Armin deals with the production of otherness on the local level, following changes in cultural identities after the disintegration of the common state.

The representation of Bosnia as an anthropological location bordering with Europe is suggested by an opening, panoramic scene of a village, and a shot of a ruined bus station, which, similar to the excavation site in The Melon Route, is a reminder of the still living memory of the recent war. There is a distinction between the physical and metaphorical distance from the border to the Croatian capital, which is now one of the capital cities of Europe. As Jurica Pavičić writes, the film reflects the peculiar position of Zagreb in the regional context of "a contact zone with modernity. Zagreb functions as a kind of limbo, an in-between zone between the Balkans and the West" (51). Even to reach this limbo reminds one of the trajectory based on overcoming obstacles in Vladimir Propp's examination of the structure of fairytales, with the difference that this journey has an ambiguous ending. While Armin and Ibro cross the official border smoothly, their arrival in Zagreb is continually delayed by a series of obstacles, which slow down the journey, prolong the metaphorical distance, and foreground it as one of the main elements of the narration. When the protagonists finally reach Zagreb, the contrast between rural Bosnia and urban Europe, where no history of the recent war is visible or even important, becomes explicit: reflections of the modern, European city in the car window, as well as the window itself, are metaphorical borders between Armin's identity and identity of Zagreb: they are also reflections of his foreignness, not only in terms of being a foreigner in Zagreb, but also in what will be his refusal to fit stereotypical representations of a disabled Bosnian war survivor as desired by the German film crew. In other words, their arrival and expectations of the German film crew suggest what could be defined as a civilizing role of Croatia's now officially being part of Europe, at least from the perspective of the Bosnian protagonists: not just that Ibro praises the cleanliness of a McDonald's in Zagreb, and what he sees as his relative's - a Bosnian migrant to Croatia - success in integration, but Armin also "depicts a German film production crew as colonialist, since they wrongly interpret the character Armin's illness [epileptic attacks which he suffers during the audition] as a consequence of war trauma (which best suits 
their cinematic interests)" (Lučić 2016, 247), and disregard his true talent - playing the accordion and, in extension, his identity, which his father thought would make him a star in Germany.

The Othering of the Bosnian protagonists begins with the recognition of their own foreignness as ingrained in subtleties of physical appearance and relationships between the body and the space. This is felt in the difference between Armin's and his father's humble casual dressing style in contrast to people wearing suits; in communication with the hotel staff, who, because of their Bosnian pronunciation, consider them a lower category of hotel guests ${ }^{[9]}$ Their lonely evening strolls through empty Zagreb also signal their foreignness. Finally, their own cultural norms no longer correspond with those expected from their family members living in Zagreb: their cousin fails to recognize them and does not know what to do with the unexpected visitors. Armin's Bosnianness is allegedly not photogenic enough for the purposes of the German film about Bosnia. In the end Armin does not feel he can act his identity; he refuses to identify himself with the character from the script, and the father and the son return to Bosnia, the anthropological place on the borders on the European Union, where history is lived and exists as a fact of everyday life, and not represented as a traumatic experience in need of interpretation.

\section{A Brief Excursion (2017; dir. by Igor Bezinović)}

In A Brief Excursion, the focus shifts from the external borders of the country to an investigation of the question of cultural identity from inside in a mixture of different types of travels and their purposes: tourism and pilgrimage, which in their own respective ways offer a possibility of escape, fulfilment and salvation. A Brief Excursion also uses the elements of European road films in its own right: as an expedition into the artistic heritage of a country, it shows how "traveling outside [emphasis in the original] of society becomes less important (and perhaps less possible) than traveling into the national culture, tracing the meaning of citizenship as a journey" (Laderman 248). In the film, a group of young festival-goers venture from the festival town Motovun on an unexpected one-day expedition to a monastery called Gradina. According to their guide Roko, Gradina is a site with valuable medieval frescoes, examples of Croatian medieval heritage, and a direct proof of Croatia's centuries-long belonging to European culture. Roko is determined that the frescoes will prove that Croatian culture is not inferior in comparison to the European one, as 
suggested by one of the participants. At the beginning of the journey he is perceived as the leader, both a tourist guide and "a false Jesus leading the group" (00:31:44). The character of the journey corresponds to the generation of the participants: in opposition to their counterparts from the previous two films, the protagonists belong to a post-war generation, without any pronounced attachments to Yugoslav history and war-inflicted traumas (00:11:06). They commence this journey without any ulterior motive, and, in the process of travel, it appears that their expedition diverts the narration from establishing the Europeanness of Croatia to indifference when it comes to the location of the country's identity. The group dissipates before reaching the destination: its participants spontaneously leave without an explanation, merging with the local environment, and, in the end, Roko disappears as well. Their journey does not have any political or cultural subtext, which was the case in the previous two films: the narrator just observes how "another empty day was going by," and then he wishes "for an earthquake or a rainstorm to wash us off. But none of that ever happened" (00:7:51). The extradiegetic voiceover narration repeatedly undermines the authenticity of the journey as visualized on the screen, and represented in a mocumentary style: even though we see the narrator on the screen, in his voice-over narration he claims that his memory of the event, the space and the people is not reliable, as he does not remember the faces and course of events.

Such ambiguity translates into the construction of space: the journey is a trajectory from the mapped geographical space into the imaginative geography of Croatia. Additionally, the journey takes place in its entirety in nature, which, in absence of any markers of human civilization such as the motorways, prolongs the distance from the point of departure, and aggravates the feeling of disorientation. This unfolds in stages, each stage signaled by the uncanny rootedness into the archetypal symbols of the identity of the region, and the encounters which are erotic, animalistic, and exoticizing, such as the encounter with three local women or an old man in the abandoned village. These encounters are announced by the traditional Istrian music played on a type of the flute called "sopile," an extradiegetic sound element, which brings "the surrounding space as a whole into play" (Williams 27). In this way the journey may be characterized as a search for a "mythscape," an uncanny local version of "an idealized bounded territory, for example... pastoral English villages, [or] rugged American frontiers or bucolic German forests" (Bell 76), which the film 
represents as an illusion. While the film festival in the Istrian town of Motovun is an authentic event, the destination is fictionalized, geographically unverified, and dispersed: Gradina from the film does not exist on the map of Istria. Instead, it is a frequent toponym that can be found across the Balkans, and it can refer to a variety of sites, from the name of mountain peaks to excavation sites. Reflecting on the journey, the narrator also admits that later, when he looked for Gradina on the map, he "found a lot of places with that name. You wouldn't believe how many of them there are, the whole country is filled with them" (1:10:00). The existence of Gradina is inextricably linked with the presence of Roko. Once the leader, the embodiment of a tourist guide and a false Jesus, disappears, the space disappears as well: "One year I visited them all, but I didn't find the one Roko took us to that summer. I looked for Roko too, but I didn't find him either. He'll show up out of nowhere sometimes, anyhow. And then we'll find Gradina again" (1:12:00).

To sum up, this short outline of representations of the trope of the journey and border-crossings in contemporary Croatian film is indicative of geopolitical and cultural changes of the country on the changeable margins of imagined Europe and the physical borders of the European Union. The borders of imagined Europe are imposed, self-imposed, and disputed, and they establish boundaries between history and trauma on one side, and dreams or hope on the other. In the films, the space, and its identity in extension, are as important as the characters who cross it: its meaning is always negotiated by the characters' sense of belonging, perception and production of space, and their reasons for traveling, and their travel contributes to the formation of identity and doubts. In this respect Croatian contemporary films may be discussed in the context of contemporary regional cinematographies, such as Damjan Kozole's Spare Parts (Rezervni deli, 2003, Slovenia), Želimir Žilnik's trilogy Fortress Europe (2000, Serbia), Marian Crisan's Morgen (2010, Romania), Cristian Mungiu's Occident (2002, Romania), and Kornel Mundruczó's Jupiter's Moon (Jupiter holdja, 2018, Hungary). If approached from a diachronic point of view, the examination of the position and the meaning of borders contributes to an examination of the space of the Balkans, represented as an area frequently crossed by different types of travelers, who, for instance in Theodoros Angelopoulos's "trilogy of silence, ${ }^{[10]}$ act as witnesses to its mythologies and histories, and also to its fluctuating borders, not only the physical, but also the metaphorical ones. As Étienne Balibar writes, "the term border is extremely rich in connotations" and "it is 
undergoing a profound change in meaning" (1). His statement is especially valid for the Balkans and Central Europe, whose history and current political and social issues are in these films addressed through the notion of travel. A comparative and a diachronic approach to this topic is a subject of my current research project.

\section{Works Cited}

Augé, Marc. Non-places: Introduction to an Anthropology of Supermodernity. Verso, 1995.

Balibar, Étienne. We, the People of Europe?: Reflections on Transnational Citizenship. Princeton University Press, 2004.

Bamyeh, Mohammed A. "Frames of Belonging: Four Contemporary European Travels." Social Text, no. 39, 1994, pp. 35-55.

Bell, Duncan S. A. "Mythscapes: Memory, Mythology, and National Identity." The British Journal of Sociology, vol. 54, no. 1,2003 , pp. 63-81.

Bezinović, Igor. Kratki izlet. Pangolin Studio, 2017.

Bishop, Peter. "An Imaginative Geography." Travel Writing: Critical Concepts in Literary and C ultural Studies, edited by Tim Youngs and Charles Forsdick, vol. 2, Routledge, 2012, pp. 141-68.

Bracewell, Wendy, and Alex Drace-Francis. Under Eastern Eyes: A Comparative Introduction to East European Travel Writing on Europe. 1st ed., Central European University Press, 2008.

Budak, Neven. "Using the Middle Ages in Modern-day Croatia." Gebrauch und Missbrauch des Mittelalters, 19.-21. Jahrhundert $=:$ Uses and abuses of the Middle Ages, 19th-21st century $=$ Usages et mésusages du Moyen Âge du XIXe au XXle siècle, edited by János M. Bak, et al. 1. Aufl. ed., Wilhelm Fink, 2009, pp. 241-62.

Chard, Chloe. Pleasure and Guilt on the Grand Tour: Travel Writing and Imaginative Geography, 1600-1830. Manchester University Press, 1999.

Clifford, James. Routes: Travel and Translation in the Late Twentieth Century. Harvard University Press, 1997.

Crisan, Marian, director. Morgen. Mandragora, Katapult Film, Slot Machine, 2010. 
"Croatia will join Schengen as soon as it meets technical criteria." Schengen Visa Info, 9 June 2018, www.schengenvisainfo.com/ep-member-croatia-will-join-schengen-as soon-as-it-meetstechnical-criteria/. Accessed 14 Oct. 2018.

Eder, Klaus. "Europe's Borders: The Narrative Construction of the Boundaries of Europe." European Journal of Social Theory, vol. 9, no. 2, 2006, pp. 255-71.

Elsaesser, Thomas, and Malte Hagener. Film Theory: An Introduction through the Senses. Routledge, 2010.

Everett, Wendy. European Identity in Cinema. Intellect, 1996.

Gardies, Andrè. L'Espace au cinéma. Méridiens Klincksieck, 1993.

Graziano, Manlio. What is a Border? Translated by Marina Korobko, Stanford Briefs, 2018.

Jelača, Dijana. Dislocated Screen Memory: Narrating Trauma in Post-Yugoslav Cinema. Palgrave Macmillan, 2016.

Jergović, Miljenko. Mama Leone. Archipelago, 2012.

Kovačević, Nataša. "Re-Worlding the Balkans. Films of Voyage to the European Union." European Journal of English Studies, vol. 17, no. 2, 2013, pp. 188-200.

Laderman, David. Driving Visions: Exploring the Road Movie. University of Texas Press, 2002.

Longinović, Tomislav. "Playing the Western Eye: Balkan Masculinity and Post-Yugoslav War Cinema." A Companion to Eastern European Cinemas, edited by Anikó Imre, Routledge, 2005, pp. 35-47.

Loshitzky, Yosefa. Screening Strangers: Migration and Diaspora in Contemporary European C inema. Indiana University Press, 2010.

Lučić, Krunoslav. "The Representation of Minorities in Contemporary Croatian Film." Umjetnost riječi, vol. 3, no. 4, 2016, pp. 231-60.

Pavičić, Jurica. "Cinema of Normalization: Changes of Stylistic Model in Post-Yugoslav Cinema after the 1990s." Studies in Eastern European Cinema, vol. 1, no. 1 ,2010, pp. 43-56. 
Propp, Vladimir. Morphology of the Folktale. Translated by Laurence Scott, University of Texas Press, 1990.

Rascaroli, Laura. "New Voyages to Italy: Postmodern Travellers and the Italian Road Film." SCREEN, vol. 44, no. 1, 2003, pp. 71-91.

Ravetto-Biagioli, Kriss. "Reframing Europe's Double Border." A Companion to East European C inemas, edited by Anikó Imre, Routledge, 2005, pp. 179-96.

Roberts, Les. "Non-places in the Mist: Mapping the Spatial Turn in Theo Angelopoulos's Peripatetic Modernism." Revisiting Space: Space and Place in European Cinema, edited by Wendy E. Everett and Axel Goodbody, Peter Lang, 2005, pp. 325-44.

Rucker-Chang, Sunnie T. "Filmic Representations of the Chinese Presence in Serbia, Croatia, Bosnia and Slovenia." Chinese Migrants in Russia, Central Asia and Eastern Europe, edited by Felix B. Chang and Sunnie T. Rucker-Chang, Routledge, 2012, pp. 199-220.

Schmidt, Branko, director. The Melon Route. Hrvatska radiotelevizija, 2006.

Spiridon, Monica. "Identity Discourses on Borders in Eastern Europe." Comparative Literature, vol. 58, no. 4, 2006, pp. 376-86.

Stob, Jennifer. "Riverboat Europe: Interim Occupancy and Dediasporization in Goran Rebić's Donau, Duna, Dunaj, Dunav, Dunarea." European Cinema after the Wall: Screening East-West M obility, edited by Kris van Heuckelom and Leen Engelen, Rowman \& Littlefield, 2014, pp. 141-62.

Sviličić, Ognjen, director. Armin. Hrvatska radiotelevizija, 2007.

Vojković, Saša. "De/re-construction of Subjectivity in Contemporary Croatian Cinema: Becoming European." New Review of Film and Television Studies, vol. 6, no. 1, 2008, pp. 83-95.

Williams, James S. Space and Being in Contemporary French Cinema. Manchester University Press, 2016.

Wood, Mary P. Contemporary European Cinema. Hodder Arnold, 2007. 
[1] The films in questions share some of the tropes commonly found in Croatian and post-Yugoslav films and fiction of the last two decades, such as a shift from the self-Balkanization characteristic of the 1990s (Longinović; Pavičić), the representation of Otherness (Vojković), dealing with warrelated trauma (Jelača), and the transition from socialist to capitalist society (Kovačević).

[2] On this topic see, for instance: Loshitzky; Wood.

[3] For instance, Mary Wood proves this in the example of Italy and Britain (Wood).

[4] On the theme of journey used to articulate a transition toward European narrative see: Kovačević.

[5] As a fictional concept and an embodiment of the European Dream, Germany is also an imagined place "elsewhere" in other films from the region with the theme of travel and migration. As Les Roberts writes, "The opening shot of [Theo Angelopoulos's] Landscape in the Mist, the third of the trilogy of silence, is of two children standing on a railway platform in front of a stationary train bound for 'Germany', a mythical place where the children believe their father, whom they have never known, can be found" (Roberts 339). In Marian Crisan's Morgen (2010), the Turkish refugee, who finds himself in a small village on the Romanian side of the Romanian-Hungarian border, also desires to reach Germany, where he apparently has a family, but which he has imagined through tourist guides.

[6] On representations of national minorities in film and in Croatian contemporary cinematography in general see: Lučić; on the portrayal of Chinese migrants in film see: Rucker-Chang. On Otherness in contemporary Croatian cinema see: Vojković.

[7] The metaphor of the American Wild West is also used in other films on the topic of borders and migration. For instance, in Damjan Kozole's Spare Parts the narration takes place in what seems to become "the European Wilderness ... a liminal zone dominated by smugglers, traffickers, criminals, and stateless refugees" (Loshitzky 24).

[8] Such crossings also resonate in other contemporary Croatian films and in literature. For instance, Miljenko Jergović's story “Nora, Like Ibsen's” from the collection Mama Leone features a Bosnian protagonist Mahir who has just arrived in Zagreb, and is not sure where to go and what to 
do. However, in contrast to Armin and his father, Mahir characterizes himself as somebody who was once from Zenica, but who is now "not from anywhere" (Jergović 322).

[9] This again recalls Mahir Kubat's conversation with a girl who approaches him and asks him for a cigarette in Jergović's story "Nora, Like Ibsen's," where he is clearly identified as someone who is not from Zagreb: "A loosey, you got a cigarette? ... No... You're not from Zagreb? ... Why's that, that bother you? ... No, it's just you don't sound like it" (Jergović 322).

[10] Angelopoulos's "trilogy of silence" refers to Voyage to Cythera (Taxidi sta Kythira, 1984), The Beekeeper (O Melissokomos, 1986), and Landscape in the Mist (Topio stin omichli, 1988).

\section{(c) (1) $\ominus$}

Creative Commons Attribution-NonCommercial-NoDerivatives 4.0 International License 